\title{
経腹膜的腹腔鏡下傍大動脈リンパ節摘出術の実際
}

市立函館病院産婦人科

山下 剛、西岡嘉宏、根岸秀明

\section{Transperitoneal laparoscopic para-aortic lymphadenectomy surgical technique}

\author{
Tsuyoshi Yamashita, Yoshihiro Nishioka, Hideaki Negishi \\ Department of Obstetrics and Gynecology, Hakodate Municipal Hospital
}

\begin{abstract}
Para-aortic lymphadenectomy up to the renal vein is the standard surgical treatment for patients with a recurrence risk of endometrial cancer. We report detailed steps of a transperitoneal laparoscopic para-aortic lymphadenectomy surgical technique. This procedure was performed in 19 patients with endometrial, cervical and ovarian cancers as a staging surgery. The median number of retrieved para-aortic lymph nodes based on the extent of lymphadenectomy from patients with cervical (up to 326B2) and endometrial/ovarian cancer (up to 326B1) was 15 and 25, respectively. Blood loss was $162 \mathrm{ml}$ in patients with endometrial/ovarian cancer and $5 \mathrm{ml}$ in patients with cervical cancer. No intraoperative complications occurred in this series. This feasible, safe transperitoneal para-aortic lymphadenectomy procedure should be considered if laparoscopic surgery, including para-aortic lymphadenectomy, is a surgical treatment option.
\end{abstract}

Key words: laparoscopic surgery, para-aortic lymphadenectomy, transperitoneal

\section{緒言}

婦人科癌における傍大動脈リンパ節摘出術（サ ンプリング術あるいは郭清術）は開腹術でのアプ ローチが標準手術として施行されているが、近年 腹腔鏡下でのアプローチが報告されつつある。一 般に腹腔鏡下手術は開腹術に比較し出血量が少な く、術後疼痛、入院期間に優れ、拡大視下での病 巣観察や精密な手術操作などの利点があるので、 適応がある場合正しく行えば開腹術より優れてい る面があるのも事実である。従って傍大動脈リン パ節摘出術においても開腹術から腹腔鏡下手術へ の置き換えが妥当かどうかは検討に值すると考え られる。当院を含む筆者が在籍した施設では、患 者が希望しその適応がある場合2008年より先進医
療として腹腔鏡下子宮体癌根治術を施行してき た。先進医療には「腹腔鏡下傍大動脈リンパ節郭 清術」が含まれており、進行期にもよるが必要に 応じてそれを施行することが可能である。子宮体 癌の先進医療承認施設は年々増加しており2012年 現在19施設に至っており、今後も増加が見达める 状態である。したがって骨盤内操作のみならず傍 大動脈リンパ節摘出術を施行する施設も今後同様 に増加していくと思われる一方、手技的にやや困 難との認識が多いためか一部の施設を除いて施行 報告例がほとんどないのも現状である。手技の標 準化のためには、安全で再現性のある手技の確立 が急務である。

腹腔鏡下での傍大動脈リンパ節へのアプローチ には経腹膜的アプローチと腹膜外アプローチ法が 
ありそれぞれ利点欠点を持っているが、執刀医の 技術レベル・施設環境を鑑みて適切なアプローチ を選択することが必要である。また、当科で行う 子宮体癌での経腹膜的腹腔鏡下傍大動脈リンパ節 摘出術は、進行頸癌での照射野決定のための 326B2領域（IMAまで）までの傍大動脈リンパ節 摘出術（サンプリング術）、あるいは腫瘍サイズ が小さい場合の早期卵巣癌に扮けるステージング 手術の際に行われる傍大動脈リンパ節郭清術と技 術的にはほぼ同一であり、それらにも応用可能で ある。

今回我々は当科で標準的に行われている経腹膜 的腹腔鏡下傍大動脈リンパ節摘出術についてその 手順の詳細を報告する。施設の状況、助手の経験 などにより施設ごとに施行方法が多様であると思 われるが、以下の方法は経腹膜法として以前の施 設でも様々な組み合わせを試した後での有用で再 現性の高い方法として行っているものである。

\section{患者および手術方法}

対象はそれぞれの癌における治療ガイドライン にて進行癌を除いた開腹術でのステージング手術 の適応となる早期癌患者（通常体癌ではIB期ま で、卵巣癌ではIC期まで）であるが、患者の状 態などを勘案して手術自体の適応は各施設での判 断となる。当該施設での倫理委員会承認の後、対 象となる子宮頸癌、早期子宮体癌、早期卵巣癌で の全患者から標準的な開腹術での手術方法の説明 を行った後に当該手術施行の選択・承諾を得、以
下の方法で手術を施行している。

\section{ポート配置および術者・助手の位置}

現在まで種々のトロッカーを様々な位置にお き、あるいは執刀医として患者右側、左側、脚間 の 3 カ所にたって乎術を試みてみた。骨盤内操作 も一度に行うため現在は臍部へのマルチアクセス ポート（SILSポートやEZアクセスなど）、操作用 ポートとして左右の腸骨窩領域に 5 ミリポート、 傍大動脈領域アクセス時のカメラ用ポートとして 恥骨部に 5 ミリポート、補助ポートとして助手用 に右上腹部に 5 ミリポートの 5 カ所にポートを配 置している（図 1 )。な掞傍大動脈リンパ節摘出

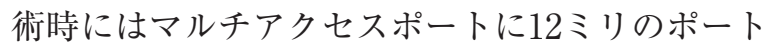
を留置する。当科ではカメラには 5 ミリフレキシ ブルスコープを用いているが、子宮筋腫手術時の ような大きな腫瘤による視野の妨げがないため直 視鏡・斜視鏡を用いることも可能である。子宮体 癌によく見られる肥満の程度（BMI30以上）によ っては気腹しても十分な術野が確保できずまた後 腹膜の展開が困難なことがありその場合良い適応 ではない。一定レベルの技術を持つ助手の存在下 では執刀医は患者脚間に立ち、第一助手は患者右 側で補助ポートおよび臍部のアクセスポートを使 用し、術野展開の補助、リンパ節の搬出やトラブ ル時の対応など様々なアシストを行い、第二助手 （スコピスト）は患者左側（トラブル時には第二 助手の右手も追加ポート挿入すれば使用可能)、 というのが他の方法に比較して安全性㧍よび緊急

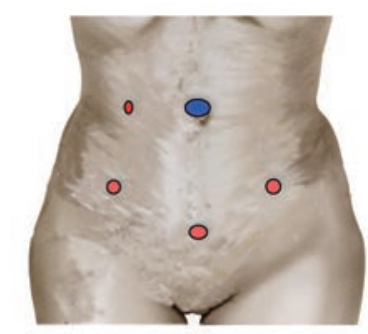

青色 : マルチアクセスポート 赤色 : 5ミリポート

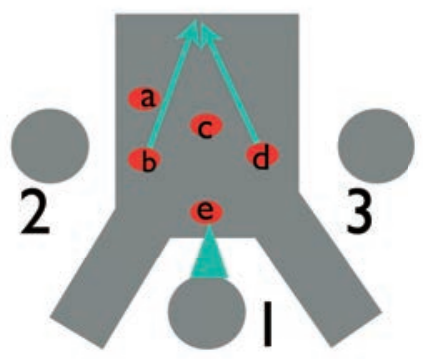

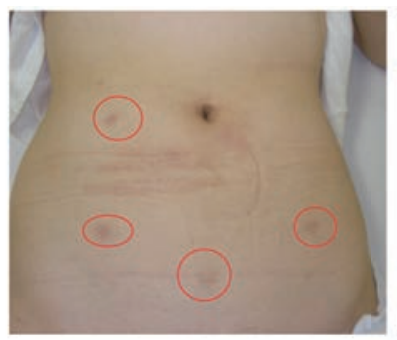

1:術者：脚間（b,dを操作用ポートとして使用）

2:第1助手 : 患者右側（aを補助ポートとして使用）

3:第2助手 : 患者左側（eをカメラポートとして使用）

cは術者あるいは第一助手がリンパ節搬出、クリップ などに使用

図 1 
時の操作性を担保した上で手術完遂に有用であっ たため、現在はこの位置で施行している。骨盤高 位の角度は通常のTLHで行う骨盤高位と同様で 良く、麻酔科の特段の指示がない限り手術終了ま で変更する必要はない。骨盤内操作が終了し傍大 動脈リンパ節摘出に移行するときに術者、助手が 位置を移動する。以下子宮体癌での標準的な手術 法を示す。

\section{手術手技}

\section{1. 骨盤内操作}

骨盤内操作時には通常のTLH同様術者は左あ るいは右に立ちマルチアクセスポートからカメ ラ、鉪子を挿入して手術を行う。当科では子宮体 癌根治術の場合、骨盤内のリンパ節転移検索に対 し標準的に骨盤内リンパ節マッピング（センチネ ルリンパ節同定）を行っている。その手技につい ては既に報告された方法に従っている1)。現時点 での子宮体癌における骨盤リンパ節でのセンチネ ルリンパ節同定の意義は術後でのセンチネルリン パ節の微小転移の検索をその目的としている。し たがって、傍大動脈リンパ節摘出術に先立ち、骨 盤腹腔内の観察、腹腔内洗浄細胞診、両側卵管の シーリング（あるいは結紮）を施行した上で、セ ンチネルリンパ節を腹腔鏡下に同定・摘出しその
後腹腔鏡下での骨盤内リンパ節摘出、子宮付属器 全摘術を施行している。これらは状況によっては 傍大動脈リンパ節摘出後に行うこともある。子宮 マニピュレーターは通常使用せず、パテントブル 一投与後に子宮腟部を胵式に縫合し牽引糸をかけ ておく。

2. 左腎静脈 (LRV) までの後腹膜切開

骨盤内操作の位置から術者・助手は傍大動脈り ンパ節摘出術の位置に移動する。まず、小腸・お よびその腸間膜を頭側に授動して後腹膜を十分に 確認する。この段階で下大動脈、大動脈分岐部、 右総腸骨動脈の走行、拍動が透見出来る。これが 出来ない様な肥満患者では、以後トラブル時に安 全な手術施行が困難となる可能性があることを念 頭に置く。右総腸骨動脈前面の後腹膜を切開し右 総腸骨動脈を露出し（図 $2 \mathrm{a} ）$ そのまま大動脈分 岐部まで切開を延長する。後腹膜切開時には右尿 管の走行に注意する。大動脈分岐部を確認できた ら、そのまま下大動脈上の後腹膜切開を延長して いく。このとき下腸間膜動脈（以下IMA）は左 側に分枝することを念頭に置き剥離展開する（図 $2 \mathrm{~b}$ )。展開に伴い下大静脈（以下IVC）の一部 も見えてくる。切開された後腹膜は伸展するが、 後の腹膜テント形成のため穿孔を作らないように 注意する。小腸の動きに注意しつつ下腸間膜動脈

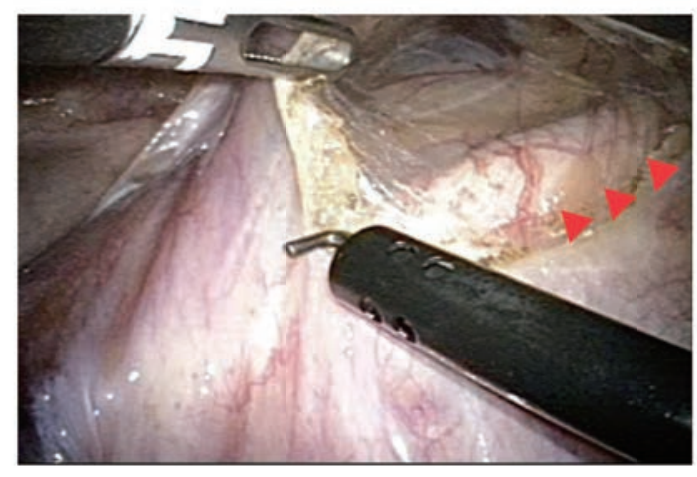

$2 \mathrm{a}$ ：右総腸骨動脈（矢頭）の露出

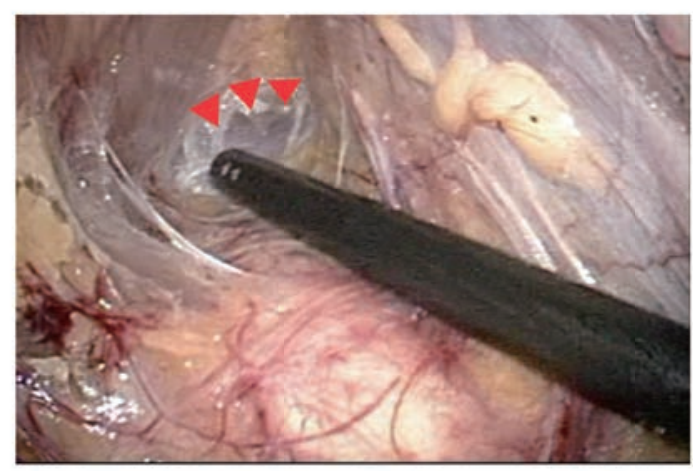

$2 \mathrm{c}$ ：左腎静脈 (矢頭) の確認

図2

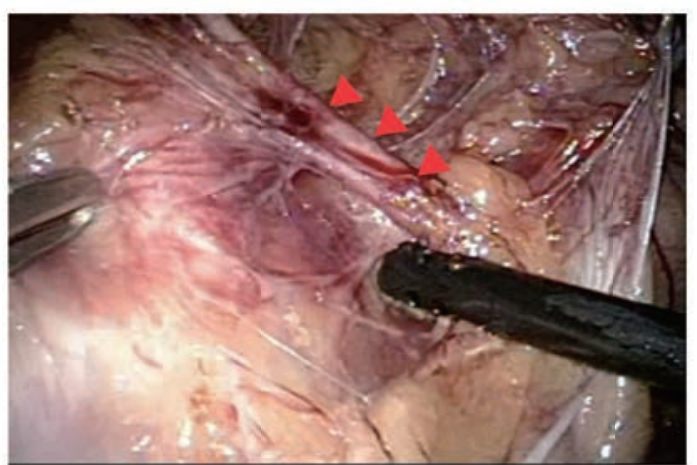

$2 \mathrm{~b}$ : IMA（矢頭）の剥離展開

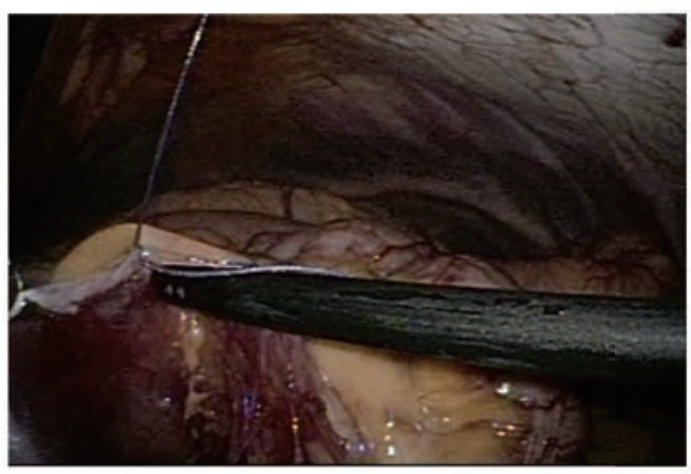

$2 \mathrm{~d}$ : 後腹膜の吊り上げ 
のさらに頭側まで後腹膜切開を延長すると下大動 脈に騎乗した左腎静脈の一部が見えるため後腹膜 切開の上限をそこに扮く（図 $2 \mathrm{c} ） 。$

\section{3. 後腹膜吊り上げによる視野展開}

左右に切離された後腹膜を縫合糸にて吊り上げ てバリヤを作ることで腸管を排除し十分な視野を 展開する（図 $2 \mathrm{~d}$ )。この術式で最も重要なパー トの一つであり、腸管が入り込むような不十分な 視野では安全な手術は施行できないためまず視野 の確保に全力を注ぐ。後腹膜吊り上げには体外か ら搬入する直針を用いたり、通常の縫合針を用い て縫合糸のみを体外に搬出する、あるいは細径の デバイスを用いる等いくつかの方法が考えられる が大差はないので自分のやりやすい方法でよい。 通常 $1 \sim 3$ 力所程度に星引を行うと本手術に十分 な視野が得られる（図 3 a ）。頸癌のようなIMA までの摘出術では右側1カ所だけでも十分である。 十分に展開されればIMAの高さまでの下大動脈 前面326B2領域のリンパ節を摘出しマルチアクセ スポートの 12 ミリポートから（図 3 b ）体外に搬 出する。12ミリポートは直接扱入部の腹膜には接 触しないためポート再発の観点からはダイレクト に 12 ミリポートを使用するより有利である。下大 動脈前面には上下腹神経が分布しているが判別可

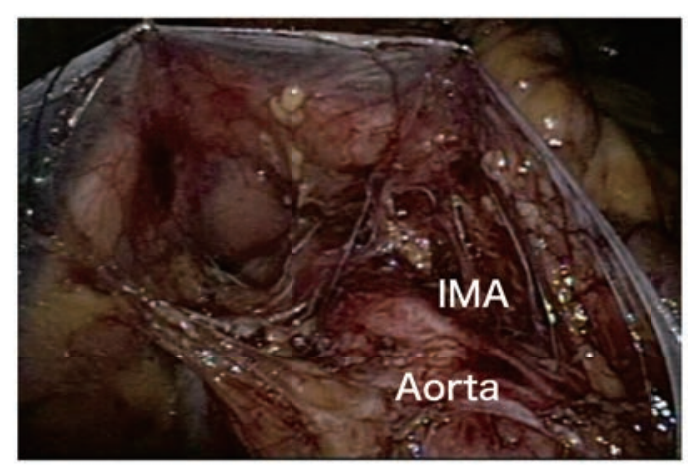

$3 \mathrm{a}:$ 腹膜の吊り上げ終了後

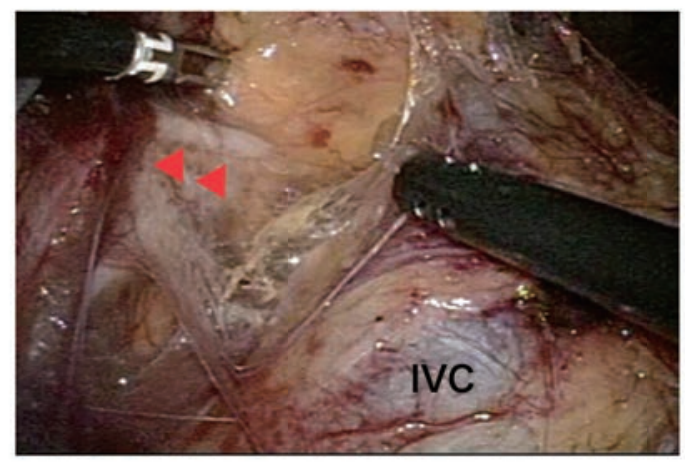

$3 \mathrm{c}$ : 右尿管 (矢頭) と下大静脈確認

図 3
能であればその部分は保存しても良い。しかし切 断しても女性の場合は特段の障害は起こらないよ うである。さらにIVCの前面も剥離展開してリン パ節を摘出する。右総腸骨静脈からIVC周辺のリ ンパ節には通常IVCから穿通枝がリンパ節内に連 絡している。リンパ節をそのまま引き抜くとIVC の穿孔部から出血するため丁寧な摘出が求められ る。穿通枝が同定できた場合にはシーリングデバ イスあるいは血管クリップで処理してから切断す る。右側の摘出についてはこの段階では右尿管が 同定できIVCの右側縁が確認できればよい（図 3 c)。

\section{4. 正中〜左側326B2領域リンパ節の摘出}

IMA分岐部を十分に展開露出し下大動脈左縁 とIMAで構成される左326B2領域にあるリンパ節 を摘出する。周辺からの出血に留意しつつスペー スを展開しまず左尿管走行の同定を試みる。尿管 が同定できれば第一助手によりIMAと尿管を左 側に授動し操作スペースを十分に確保する（図 3 d)。左卵巣静脈（LOV）ないし動脈が尿管と平 行に走行していることがあるのでそれらの損傷に 注意する。スペースが十分にとれれば下大動脈左 側のリンパ節は拡大視野で確認できるため摘出は 容易である（図 4 a ）。相当量のリンパ節がen

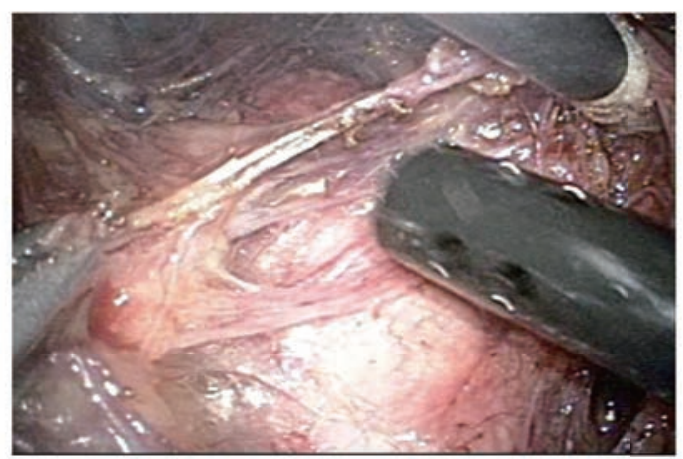

$3 \mathrm{~b}$ : 下大動脈前面のリンパ節摘出

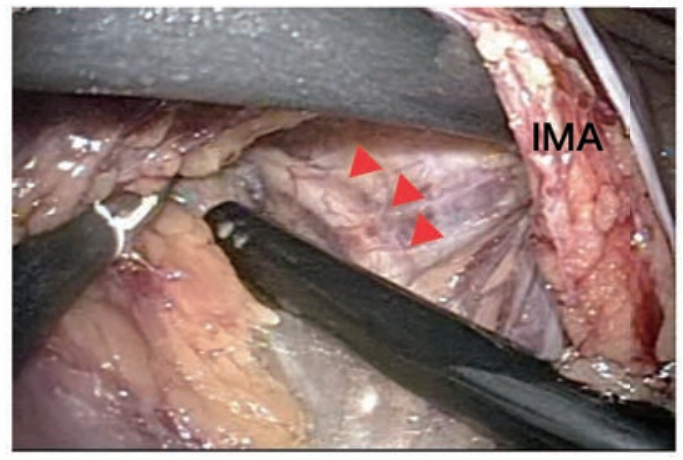

$3 d$ : 左尿管 (矢頭) の走行確認と授動 


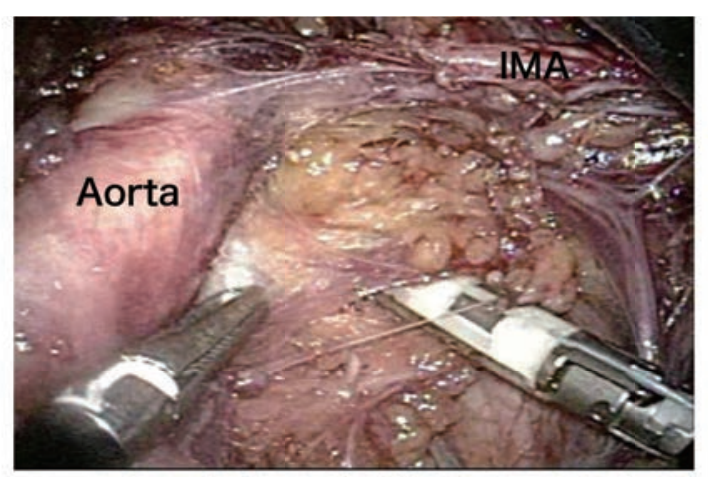

$4 \mathrm{a}:$ 左326B2リンパ節

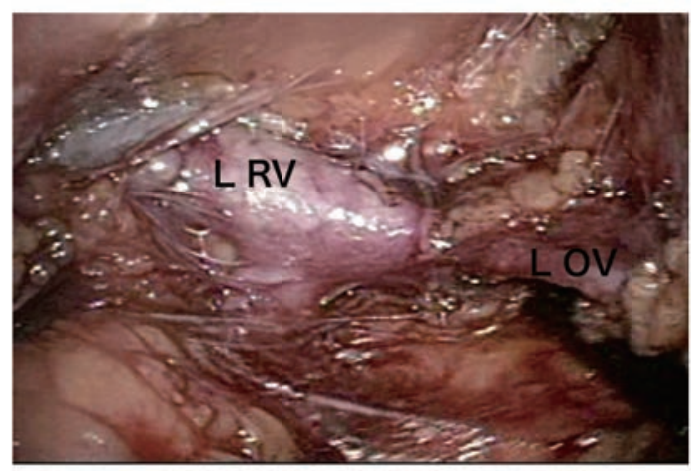

$4 \mathrm{c}:$ 左326B1領域の展開

図 4

blockに剥離されるが腹腔鏡では視野・操作の妨 げになるので、必要に応じて数個に分割して摘出・ 搬出し、常に良好な視野を確保しトラブル時に備 える。この郭清の範囲内には第 3,4 腰動静脈が 存在している。これらは切断可能であるが、動脈 については稀に脊髄梗塞の原因になることがある ので可能であれば切断せずに確保しておく。リン パ節の上縁はIMAをやや下方にくぐった左326B1 領域の確認ができたところで一時的に切断する。 左総腸骨動脈領域のリンパ節は左326B2領域スペ 一スの展開により容易に認識され摘出可能となる ので必要であれば後に追加する。子宮頸癌での IMAまでのリンパ節摘出ではこの後動静脈間の リンパ節・IVC右側周辺のリンパ節を摘出 $(326 \mathrm{~B} 2$ 領域）して終了とする（図 4 b )。

\section{5. 左326B1領域リンパ節の摘出}

左326B2領域の郭清が終了するとその部分の久 ペースが広く展開されている。IMAを乗り越え た部分からさらに左326B1領域の方向に剥離展開 し、左腎静脈方向に尿管の走行を確認する。尿管 の位置は下大動脈方向に偏移していたり、重複尿 管の場合もあるので術中には常にその存在を認識 しておく必要がある。下大動脈の前面および左縁 から左326B1リンパ節を摘出する。左卵巣動脈が

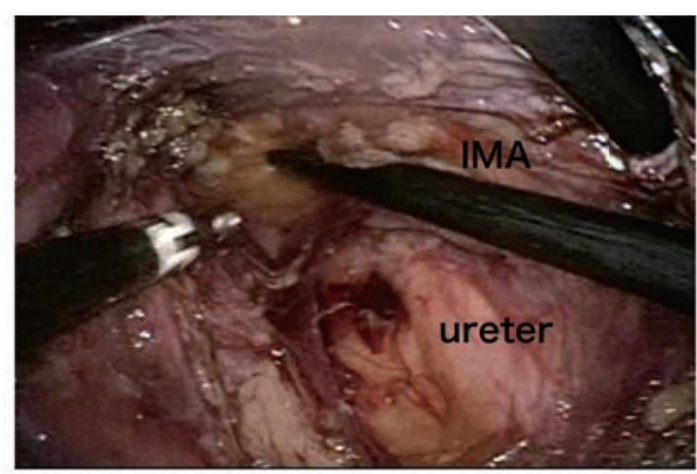

$4 \mathrm{~b}:$ 左326B2リンパ節摘出後

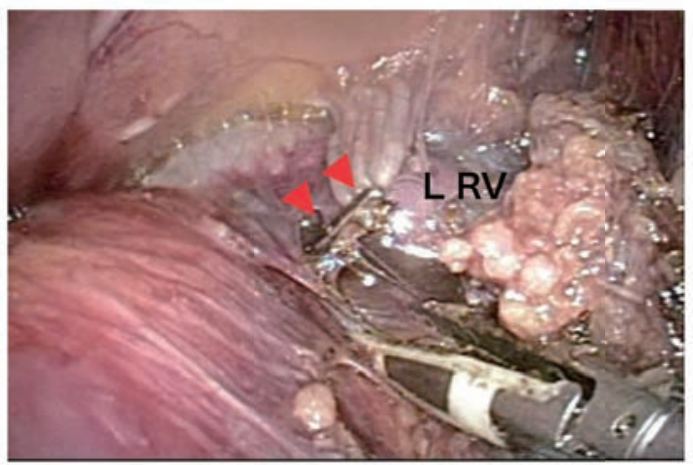

$4 \mathrm{~d} ：$ リンパ管のクリッピング（矢頭）

見えた場合は切断する。左腎静脈下縁に到達する 前に左腎静脈から左卵巣静脈の分岐がみえてくる ので損傷に注意する。この外側にGerota's fascia が存在する。リンパ節は 1 方向からではなく尿管・ 左卵巣静脈の位置を頼りにその内側の部分の比較 的展開容易な部分から剥離を進めていく。次第に 左卵巣静脈、左腎静脈、第 2 腰静脈が確認できる ようになる（図 $4 \mathrm{c}$ )。第 2 腰静脈 (LV) は上行 腰静脈のほかに上記のいずれかの静脈に連結して いることが多いが、剥離展開初期の時点ではどの 血管に接続しているかは不明なので安易な剥離操 作は血管破綻・出血の原因となる。出血時の対応 は吸引により視野を確保し出血点を素早く確認後 クリッピングあるいはシーリングないし縫合する ことで対処するが、この部分の強出血への対応は 腹腔鏡下では最も難易度が高いため、慣れないう ちはあらかじめガーゼなどを挿入しておき出血時 には直ちに圧迫し視野を確保できるようにするの もよい。出血時の対応の手順を常に確認しておく 必要がある。またこの部分では左腎静脈を乗り越 え乳び槽に入っていくリンパ管が視認できること も多いため、この部分のリンパ節摘出時には乳び 漏を予防するためにシーリングだけではなく結紮 ないしクリッピングすることが望ましい（図 4 $\mathrm{d})$ 。腹腔鏡下ではきわめて明瞭に左腎静脈の走 
行が確認できるので腎静脈全体を露出する必要は なく、従ってリンパ節摘出の上限もここに置く。 左側全体の摘出が終了すると腎静脈のやや頭側に 位置する左腎動脈（LRA）の一部も確認できる こともある。摘出後のスペースはサージセルなど で圧迫しておくのもよい（図 5 a)。

\section{6. 右傍大動脈領域リンパ節の摘出}

左側のリンパ節摘出が終了したら、右側326B2 残り部分 326B1領域（右尿管、右卵巣静脈、 IVC）下大静脈前面のリンパ節摘出に移行する。 当科では右側については右腎静脈の全面的な展開 は行わずに上縁として右卵巣静脈のIVC分岐部周 辺までとしている。IVC周辺から穿通枝の存在に 注意しつつ丁寧にリンパ節を剥離していく。左側 同様に右卵巣動脈は切断しさらに上部を展開する と卵巣静脈分岐部が確認できるため、その周辺の リンパ節の摘出が終了したら右側326B1領域の摘 出は終了とする。

\section{IVC・下大動脈間リンパ節の摘出}

引き続き326B1 IVC・下大動脈間リンパ節を郭 清していく。左側同様に腰動静脈の存在に留意す る。椎体が確認できるまでの深さを剥離展開する が、この部分のスペースは狭いため、助手に下大
動脈を授動してもらい必要なスペースを確保す る。この部分のリンパ管にもクリッピングしてお くことが望ましい（図 5 b )。326B1動静脈間リ ンパ節の摘出上縁は左腎静脈の下縁が確認できる のでその高さまでとする（図 5 c ）。またこの部 分も鉗子先端の動きが制限される部分であり、デ バイスの左右持ち替えを必要とする部分でもある のでそのような操作には慣れておく必要がある。 引き続き $326 \mathrm{~B} 2 \mathrm{IVC}$ ・下大動脈間リンパ節を摘出 する。326B1同様に施行する。最下端の分岐部で の右総腸骨静脈の破綻には特に注意が必要である (図 $5 \mathrm{~d}$ )。必要に応じてこの部分と連続的に仙骨 部のリンパ節を摘出してもよい。

\section{結 果}

上記の方法にて当科にて 2010 年 4 月以降子宮頸 癌、子宮体癌、卵巣癌患者 19 名に腹腔鏡下傍大動 脈リンパ節摘出術を行った。結果は表 1 に示した。 術中に特段のトラブルはなくすべての症例で問題 なく終了したが、326B1領域にクリッピングしな かった 1 症例で術後乳び漏が発症した。絶食補液 およびサンドスタチン投与にて改善した。術後病 理組織で傍大動脈リンパ節転移陽性例はなかっ た。予後としては現時点で最長 30 ケ経過した段 階であるが、子宮頸癌ではIIIB期 1 名が局所制御

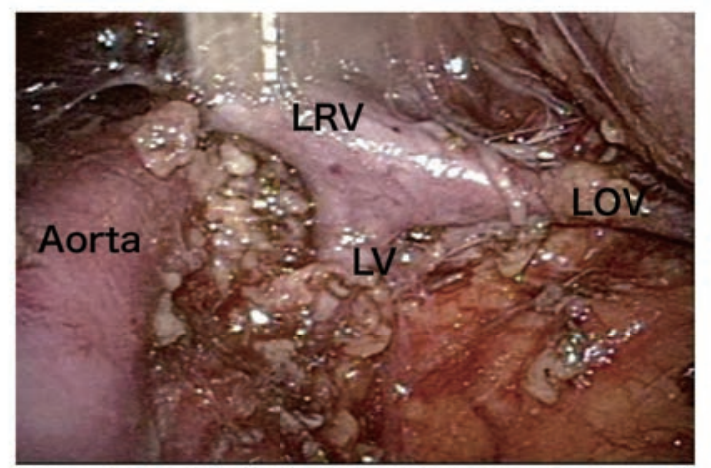

$5 \mathrm{a}:$ 左326B1リンパ節摘出後

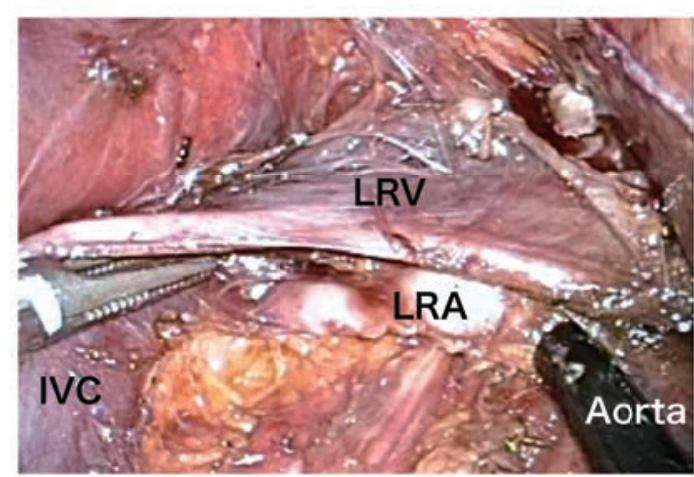

5 c：動静脈間326B1リンパ節の摘出

図 5

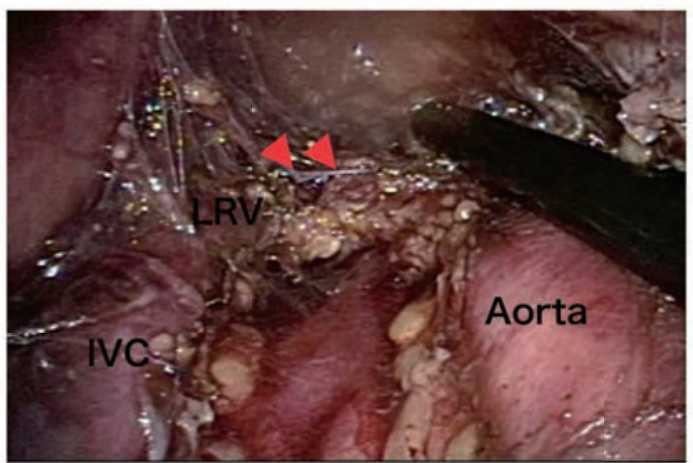

$5 \mathrm{~b}$ : クリッピング（矢頭）

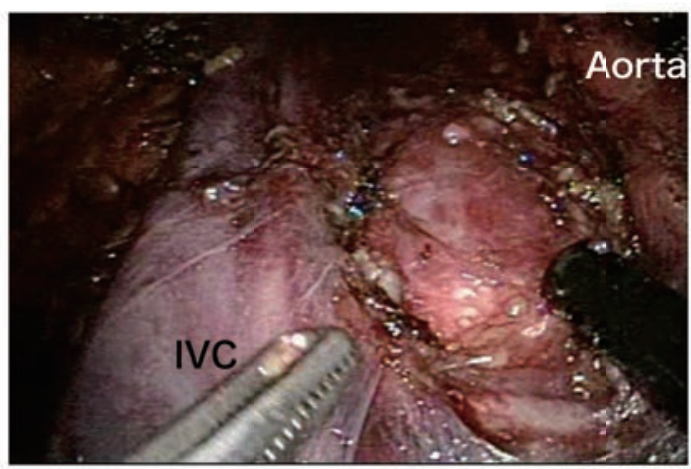

$5 \mathrm{~d}$ : 動静脈間326B2リンパ節の摘出 


\begin{tabular}{ccccc}
\hline & 症例数 & 手術時間(分) & 出血量 $(\mathrm{g})$ & PAN個数 \\
\hline 子宮頸癌( 326B2) & 12 & $96(68 \sim 129)$ & $5(2 \sim 30)$ & $15(3 \sim 22)$ \\
子宮体癌 /卵巣癌( 326B1) & 7 & $* 322(240 \sim 388)$ & $162(95 \sim 470)$ & $25(9 \sim 45)$ \\
\hline
\end{tabular}

*子宮体癌 · 卵巣癌根治手術全体の手術時間

不良にて死亡した以外は全員無病生存している。 子宮体癌ではIA期漿液性腺癌 1 名で初回治療後 再発 (肺転移) し現在治療中である。卵巣癌では 経過観察中である。

\section{考察}

本邦では安藤らにより腹膜外アプローチ法での 腹腔鏡下傍大動脈リンパ節郭清術が2003年に報告 され2)、それ以降数施設から腹腔鏡下での傍大動 脈リンパ節へのアプローチについて学会報告など が行われている。経腹膜的あるいは腹膜外アプロ 一チ法にはそれぞれ特徵があるが、光部ら ${ }^{3)}$ が指 摘しているように経腹膜的アプローチ法での最大 のメリットは開腹での視野とほぼ同一であるため 解剖などが直感的に理解しやすく、またそのため に大動静脈損傷など腹腔鏡での修復困難な重大な トラブル発症時でも開腹術に切り替えた場合素早 く目標にアプローチでき、比較的短時間にリカバ リーが可能なことである。一方、我々の方法での 問題点の一つは左側あるいは右側での手術位置と 比較し、腎静脈付近での操作は両鉗子間の triangulationが鋭角となりまた鉗子長の限界付近 での操作となるため、鉗子操作の難易度が高くな り左右の 5 ミリポートからでは単孔での操作に近 似した鉗子の動きが主体でやや困難となることに ある。従って頭側のリンパ節摘出の上限は腎静脈 下縁となり、この部分を超えた頭側に腫大リンパ 節があった場合には、臍部の 12 ミリポートを利用 するか補助ポートを上腹部に追加して行う必要が ある。しかしながら当科で行う様な診断目的の早 期癌でのステージング手術であれば今回の方法で 十分に施行可能である。ポート配置や術者位置に ついては、腹腔鏡下手術の大きなメリットの一つ である整容性も考慮すると骨盤腔内の操作も同時 に行うために両方を過不足なく行える位置である ことが望ましいと思われる。前施設での 10 例程度 の手術経験も含め種々の組み合わせを試みてみた ところ、左右のどちらの位置に立っても問題なく
施行可能ではあるが、助手のカメラの位置やトラ ブル時の鉗子位置・操作に工夫が必要と思われフ レンチスタイル（術者が左手でカメラを持ち助手 と一緒に鉗子操作を行う) での対応を余儀なくさ れることもあった。本手術は助手の修練度により 手術の難易度が大きく異なってくる側面もある が、今回当科で行っている手術位置・ポート配置 であれば多少の改善点があるものの助手の能力に 過度に依存することなく手術の再現性を担保でき る手術方法と思われた。その他、患者に起因する 問題点 (高度肥満、大動脈の屈曲 - 石灰化、動静 脈の破格等）も手術を困難にする条件であり、多 少の工夫では解決困難と判断された場合はいたず らに手術を継続するのではなく速やかに開腹移行 すべきであろう。また腎血管・尿管の破格はその 処理の方法によっては術後に部分的腎梗塞・水腎 症などを招く可能性があり注意を要する゙)。

開腹あるいは腹腔鏡下に関わらず、子宮体癌 (あ るいは卵巣癌)における後腹膜リンパ節郭清では、 卵巣動静脈近傍のリンパ節に癌細胞が進展する可 能性を考えるとその摘出範囲については326B1領 域（腎静脈下縁）までとしても、摘出個数により 「郭清」とすべきか「サンプリング」とすべきか は治療ガイドラインにおいても個数の記載がない ため、未だ明確なコンセンサスの形成がなされて いない状態が続いている。諸外国の報告ではアプ ローチ法に関わらず腹腔鏡での傍大動脈リンパ節 摘出数はほとんどが15個以下で、20個以上という 報告はきわめて少ない ${ }^{5-13)}$ 。UICC第 6 版規約によ ると 11 個以上のリンパ節を、第 7 版では 6 個以上 摘出した場合病理学的に「郭清」となる ${ }^{14)}$ 。施設 による病理部での病理検体の処理方法にも差があ るために一概には言えないが、摘出個数について 本邦と諸外国で重要性の認識に差がある可能性を 示唆している。このことは子宮体癌治療全体の中 での傍大動脈領域のリンパ節摘出の臨床的意義の 解釈の差となっていると思われる。本邦において 櫻木らはSEPAL study ${ }^{15)}$ の結果からは傍大動脈 
リンパ節の摘出個数の中央值は 23 個であり、治療 的意味も含めた場合には傍大動脈リンパ節領域の 摘出には最低でも 10 個以上の摘出が求められる ${ }^{16)}$ としており、本邦では腹腔鏡下に行うステージン グ手術としても開腹術での手術成績と共通の臨床 的評価を行うためには上記の条件を満たす必要が あると思われる。今回当科の手術方法では摘出個 数の中央值は24.5個であった（頸癌での326B2 ま ででは中央值15個）ため、開腹術の置き換えとし ての腹腔鏡下手術としては妥当と考えられた。個 数による「郭清」か「サンプリング」かの評価は 今後の検討を要すると思われため、今回本術式を 「傍大動脈リンパ節摘出術」とした。そもそも摘 出個数の違いによる予後評価についてのランダム 化試験が出来ない現状での摘出意義としては診断 的意義が重要視されるため、ステージング手術と しては摘出個数も重要であるが摘出範囲も同様に 重要であると思われる。またそのような手術目的 であれば、転移の可能性は低いが診断手技として 傍大動脈領域のリンパ節摘出が必要な症例では腹 腔鏡下手術はよい適応と考えられる。

腹腔鏡ではビデオ上、手術手技のすべてが記録 され誰にでも何度でも術式およびその郭清範囲・ 程度が確認できる。そのため次回手術の検討や手 術教育にも非常に有効であると考えられる。ビデ 才上IMA，左尿管、左腎静脈下縁、左卵巣静脈、 腰動静脈、右尿管、右卵巣静脈、右腎静脈下縁部 分が確認され、それぞれのリンパ節が十分に摘出 された結果として各スペースの解放が確認され術 後病理診断にて十分な摘出個数が確認されれば、 開腹でのステージング手術から腹腔鏡下でのステ ージング手術への置き換えというこの術式の目的 は達成されたと考えられる。

本論文の要旨は第52回日本産科婦人科内視鏡学 会において発表した。

\section{参考文献}

1) Yamashita T,et al.: Management of pelvic lymph nodes by sentinel node navigation surgery in the treatment of invasive cervical cancer: Int J Gynecol Cancer 2009;19:1113-1118.

2) Andou M, et al::A new approach for accessing retroperitoneal space using a 5 -mm [corrected] visual access cannula. Surg Endosc 2003;17:11581161.

3 ）光部兼六郎、木川聖美、石本真紀、野村英司：当科
における経腹膜アプローチによる後腹膜リンパ節郭 清術、産婦人科治療、2007; $4: 431-434$.

4 ) 佐藤洋一：傍大動脈リンパ節郭清中のコツ、産婦人 科の実際、1997；46：721-729.

5 ) Dennis R, et al.: Laparoscopic Pelvic and Paraaortic Lymph Node Dissection: Analysis of the First 100 Cases1. Gynecologic Oncology 2001; 82:498-503.

6 ) Köhler C, et al.: Laparoscopic paraaortic left-sided transperitoneal infrarenal lymphadenectomy in patients with gynecologic malignancies: technique and results. Gynecologic Oncology 2003; 91:139-148.

7 ) Mehra G, et al.: Laparoscopic extraperitoneal paraaortic lymphadenectomy: a study of its applications in gynecological malignancies. Gynecologic Oncology 2004; 93:189-193.

8 ) Kfhlera C, et al.: Introduction of transperitoneal lymphadenectomy in a gynecologic oncology center: analysis of 650 laparoscopic pelvic and/or paraaortic transperitoneal lymphadenectomies. Gynecologic Oncology 2004; 95 :52-61.

9 ) Thavaramara T, et al.: Results of laparoscopic pelvic and/or para-aortic lymphadenectomy in gynecologic oncology patients in Bangkok Metropolitan Administration Medical College and Vajira Hospital. J Med Assoc Thai. 2008 91:619-24.

10) Lee JH, et al:: Laparoscopic-Assisted Staging Surgery for Korean Women With Endometrial Cancer. JSLS 2008;12:150-155.

11) Rafii A: A comparative study of laparoscopic extraperitoneal laparoscopy with the use of ultrasonically activated shears. American Journal of Obstetrics \& Gynecology 2009; 370:e1-5.

12) ZHANG H, et al.: A cohort study evaluating paraaortic lymphadenectomy in endometrial cancer. ONCOLOGY LETTERS 2012; 4:1361-1365.

13) Fagotti A, et al.: First 100 early endometrial cancer cases treated with laparoendoscopic single-site surgery:a multicentric retrospective study. American Journal of Obstetrics \& Gynecology 2012; 353:e1-6.

14) Corpus Uteri: AJCC Cancer Staging Manual. 7thed, 2009; 403-409, Springer, NY.

15) Todo Y, et al.: Survival effect of para-aortic lymphadenectomy in endometrial cancer (SEPAL study) : a retrospective cohort analysis. Lancet 2010; 375:1165-72.

16）櫻木範明、藤堂幸治：子宮体癌の傍大動脈リンパ節 郭清の治療的意義、癌の臨床、 $2012 ; 58: 1-10$. 